O. Amosha, Acad. of NAS of Ukraine, Dr. Sc. (Econ.), orcid.org/0000-0003-0189-3819,

Yu.Zaloznova, Dr. Sc. (Econ.), Senior Research Fellow, orcid.org/0000-0003-3106-1490,

D. Cherevatskyi, Cand. Sc. (Tech.), Senior Research

Fellow,

orcid.org/0000-0003-4038-6393
Institute of Industrial Economics of National Academy of Sciences of Ukraine, Kyiv, Ukraine, e-mail: zaloznova @nas.gov. ua; cherevatskyi@nas.gov.ua

\title{
REGIMEOLOGY OF COAL MARKETS
}

Purpose. Consideration of the theoretical and practical aspects of establishing and changing the operating modes of coal markets

Methodology. The main methods of research are scientific abstractions, analysis and synthesis. Performance of work provides for the presentation of the concepts of transactions (market, hierarchy, hybrid), the definition of the main modes of functioning of existing coal markets, justification of the reasons of change of the modes of coal markets, the use of regimes to achieve a new market equilibrium, the interpretation of the results of observations in relation to Ukrainian realities.

Findings. The coal markets are in the regime of economic networks (a hybrid form) most of the time and only in cases of essential violations of demand or the offer they switch over to the market modes of price balancing. At the same time, there is an activation of regimes of equilibration of the interests of market participants, which return the system to network operation.

Originality. It is shown that the world coal markets mainly function in a hybrid mode, more precisely, in the mode of economic networks.

Practical value. Ukrainian thermal power engineering, which operates mainly in inter-sectoral hierarchy, is forced to resort to establishing a network of relationships with suppliers of coal resources, such as American companies, due to the loss of government control over anthracite sources. The pricing system for coal, currently implemented in Ukraine, is based on European market indices, which implies that its characteristic formula "Rotterdam +" is groundless and leads to negative economic effects for domestic consumers of electric power.

Keywords: coal products, coal market, regimeology, market modes

Introduction. The actuality of the issues of commodity markets functioning becomes crucial time to time. As a rule, this happens on a sudden change in the prices of resources. Against the background of the raw supercycle of the 2000s, for example, oil, metal, coal, fertilizers, etc. became first much more expensive and after almost a decade and a half much became cheaper. Moreover, it turned out that the trade, in particular, in coal in the "quiet" years is usually carried out in a non-market way. The American phenomenon of relations between coal mining and power generating enterprises in 1987 was has been described by Paul Joskow and subsequently developed by Claude Ménard the idea of Oliver E. Williamson about hybrid organizations made it possible to classify relations in this area as network ones. The market time as such occurs only in the years of shocks and apparent instability. Regime changes have a deep impact not only on outsiders of the primary industries, but also on the leading market players. For example, the American largest private coal company in the world, Peabody Energy, filed in 2016 for bankruptcy statement and more than half of the Australian mines engaged in thermal coal sector became unprofitable.

Coal mining companies are adapting to regime change empirically, based upon their behavior, without having theoretical ground. For example, if US firms have reduced the scale of activity, expecting improvement in

(C) Amosha O., Zaloznova Yu., Cherevatskyi D., 2018 market conditions, the Asian ones, on the contrary, have chosen the regime of increasing production, which further raises pressure on prices, but provides economies of scale and keeps competitors from the USA and Canada from expansion into the Eastern markets.

It is appropriate to talk about regimes, since any other definition is not so informative. Now therefore, this article is about two things: coal markets and their regimes of existence.

Analysis of the recent research and publications. A large number of modern theoretical and practical studies are devoted to the problems of functioning of coal markets. The paper about the use of gravity models in minerals trade, particularly coal, can be considered as an example of theoretical work [1]. An important point of the paper (although it is devoted to another issue) is the evidence that at a certain time trade flows can be significantly influenced by long-term contracts or simply trade habits. Moreover, the topic of networks in coal trade included also in study [2], but already in the graphic-analytical aspect. It provides insight into the evolution of the international coal products trade over the past 16 years, as well as the difference between pre-crisis and post-crisis periods.

The economic community continues to be interested in the cyclical nature of the phenomena. Thus, the article [3] studies the cycles of price fluctuations in the commodity markets, including coal ones, for 160 years. 
At the same time most of the practical work is limited to the descriptions of the global coal markets in terms of export-import relations; they are devoted to trends, the specifics of their development [4-6], the impact of other kinds of fuel, for example, shale gas [4, 5].

Unsolved aspects of the problem. However, none of the considered publications explain the reasons for the functioning of coal markets in the market, hierarchical or hybrid regimes, as well as the reasons for their transition from one regime to another one.

Lyashenko V.I., who made his monograph as introduction to economic regimeology, distinguishes two separate concepts: the regime as the organization of activity and the regime as a means of achieving the target goal [6], but, of course, without reference to the above conceptual framework to the problems of coal markets.

Objectives of the article. The objective of the paper is to consider the theoretical and practical aspects of establishing and changing the modes of functioning of coal markets.

Methods and sequence of conducting research. The main research methods are scientific abstractions, analysis and synthesis. The study provides for the following points: consideration of the concepts of transactions (market, hierarchy, hybrid), definition of the main modes of functioning of existing coal markets, the rationale for reasons of changing the regimes of coal markets, the use of regimes to achieve a new market balance and interpretation of the results of observations in relation to the Ukrainian realities.

Presentation of the main research and explanation of scientific results. The impossibility of the existence of mankind without grain, oil and other vital goods made price regulation the main purpose of the commodity market institute. The commodity prices must be relatively low and stable. Bread, salt, copper and other riots of the past forced the present civilization to develop institutions of prevention of similar phenomena. Therefore, prices on world commodity markets are normally closely related to the average global costs of production factors - labor, capital, natural and material resources while the countries that have the appropriate political and military influence in a particular region are trying to the maintenance of order in the markets.

According to modern views there are three main forms of transactions: market, hierarchy and hybrid. The classic market includes stock exchanges, with their open competition, transparency of transactions and price variability. Classical hierarchies formed by firms, including large holdings. Among hybrid organizations in the context under consideration the most important are economic networks representing organizations with "bi-or multilateral dependence, when this dependence is so strong that it requires close coordination, but not enough to cause full integration" [7].

Conformity to these three forms can be found at the mega level. The market is a free international trade; the hierarchy is the relationship of the metropolitans with the colonies; the hybrid is the close long-term economic relationship of the independent national economies with the respect to commodity turnover. Hybrid rela- tions at present are supported not through "gunboat diplomacy", but, nevertheless, oil from Venezuela is almost completely exported to the United States.

Dominant countries organize the production of raw materials, protect commodity flows of raw materials from competitors and quote prices for raw materials in their currency. Although the market is formally open, large flows of goods are actually tied to certain monopoly suppliers. Therefore, oil prices are traditionally set by OPEC, grain prices - by the USA and Canada, and others.

The maximum entropy is typical for markets, the minimum - for hierarchies. According to the historian David Christian: "... the trend to increase entropy - the pursuit of disorder - can by itself be an engine that creates order ... the Energy of falling water can cause water drops to be released upwards or the current of the river can generate vortices in which part of the liquid moves against the main flow" [8]. It is natural when the construction of a hierarchical structure suddenly turns into the activation of market relations, and vice versa - a trend of centralization, vertical integration of elements can appear on the way to the market.

It is known that with a pure monopoly the manufacturer dictates the price; with a bilateral monopoly (the buyer-monopolist and the seller-monopolist), the price is a compromise; with a pure monopsony the buyer dictates the price, but risks losing the suppliers; oligopoly the policy of each manufacturer becomes "the art of possible". The main challenge for international commodity markets is, therefore, to ensure conformity of supply and demand. If there are five sellers and four buyers - the price of raw materials will fall to the "prime cost" of manufacturers of goods; if there are four sellers and five buyers - the price will rise to the "prime cost" of buyers - it will grow while the processors of raw materials keep the reason to buy it. With stable demand the price in the system of minerals manufacturers is always set at the minimum profitability of the closing production, that is, above the value of the maximum operating costs in the industry plus the bank rate.

Modern marketplace trading operates with two prices - the price of the underlying asset and the price of the futures contract. The difference between the market value of the underlying asset and the futures price is called the basis. If the market is normal, the basis is negative, i.e. the futures price is higher than the price of the underlying asset. This case is called contango (forwardation). The further the current date is from the expiry date (completion date) of the trade, the stronger contango is. As the expiration approaches, this difference becomes smaller and even disappears. The case contrary to contango is called backwardation or back. The basis for the back is positive - in contrast to the negative value for contango. The cash price of the goods in the next period for consideration is growing rapidly.

The contango situation is a situation of a stable market, where the supply of commodities fully meets the demand and there are even significant reserves of any goods. The case of backwardation occurs if the demand is significantly ahead of supply, the goods are lacking or 
their stocks are extremely limited. It is believed that the mode of contango and low prices corresponds to seller's ("bear") markets and the state of backwardation - to the buyer's markets (heavy or bull markets). Backwardation is a situation of panic, which eventually passes and is replaced by a situation of a quiet market - contango, but the "bull" dynamics associated with a steady increase in market prices can continue for a long time, as it happened in the same raw material super cycle of the 2000s. But the phenomena inherent in the past super cycle showed that contango is the regime of the overwhelming dominance of economic networks and the back is the activation of market relations.

Contango and backwardation are convenient for the integral characteristics of the markets, even if the trade is not conducted according to the exchange rules.

Despite the fact that coal and oil are the main energy resources for modern civilization, the structure of coal markets is quite different and the mechanisms of its trade differ greatly from oil markets. Oil, along with other vital commodities, forms the basis of commodity markets or, as they are also called, commodity markets (commodity - consumer goods) and serves as an apparent exchange commodity. Coal is not so popular in commodity markets. It is not often mentioned either among the solid commodities, which include produced or extracted products (oil, gold, metals) or among the products of the energy group, where oil, diesel, gasoline, fuel oil and propane prevail.

Global coal mining comes to 7 billion tones. But, no more than $20 \%$ of the extracted coal comes through international trading platforms. The rest - domestic consumption - is consumed where it has been extracted, i.e. within the national economy. Some national economies, while meeting their needs for metallurgical and thermal coal resources, do not use the services of foreign markets at all, others, like Japan and South Korea, do not have domestic markets at all - all coal is imported.

The most common combination is when there is a purchase of the missing amount of fuel or raw materials for coking, but there are transactions for the sale of some coals and the purchase of other coal grades, which gave rise to the concept of "net importer", "net exporter", depending on whether the export or import prevails. China has gained a strong reputation as a net importer, although until 2007 it had been one of the world's leading exporters of coal products.

Sea trade accounts for $90 \%$ of turnover of the total amount of coal sold. Most of the coal products transported by sea (almost $80 \%$ ) are fuel for power plants, the rest are raw materials for coking.

Futures exchanges for coal in modern history have taken root in the USA, Europe and Australia only in modern years, much later than other commodity exchanges. The have been only over-the-counter coal markets.

The reason, mainly, consists in heterogeneity of coal production, in strong dependence of its quality on ash content, humidity, sulfur content, yield of volatile, size of material, and others. Therefore, the main share of the international, as well as national, trade in coal goes through the checked channels on the basis of bilateral contracts. Coal is a commodity that is mostly not sold publicly. This is a product of relationships, rational contracting. Distribution of coal occurs mainly on a hybrid basis, through strong spikes of suppliers and consumers of coal fuel.

Often long-term contracts are concluded because of the need for large investments in projects important for both sides, despite the fact that the determining factors are the quality of coal, the convenience of its delivery, and others. Thus, according to Paul Joskov the contracts for the supply of power generating coal in the Western States of the United States on average have a significantly longer duration than in the Eastern States. The more specific the assets are, the longer the contract period is: suppliers and consumers try to stand together, forming economic networks. But the situation, as shown in [1], can be explained in a much more prosaic manner through habit.

Hybridity of domestic markets has its own price specifics. They are not characterized by dynamism. In the space of economic networks and, particularly, hierarchies in the form of vertically integrated corporations, there are not volatile market prices, but almost planned indicators. In the chains "coal-coke-metal", "coal-energy", which were common in post-soviet economies, a transfer pricing and sophisticated schemes of tax optimization prevail.

Sometimes network capitalism permeates importexport ties spreading within holding groups under the guise of cross-border or foreign sectors of the national coal industries. The names "cross-border" and "foreign" are associated with the creation of coal branches in other countries, which is becoming quite common. One of the first structures which implemented overseas coal mining (a cross-border sector) was the German Ruhrkohle company. Until 2003 its subsidiary company RAG Coal International owned 16 mining companies outside Germany: thirteen in the United States, two in Australia and one in Venezuela. In 2002 these enterprises produced about 71 million tons of coal mainly for sales to German consumers. Japanese, Korean corporations are well represented in Australia - they own the assets of local enterprises, it is their cross-border coal sector (a community of national companies that have moved part of their business to other countries). The foreign sector is a community of foreign companies in the host economy. The relevant coal structures are also in Ukraine: SCM Corporation owns a coal mining company in Appalachia (USA) - this is the cross-border sector; coal companies of the Russian Evraz Group, supplying raw materials for coking to their plants in Ukraine form the foreign sector. Formally remaining the import, such supplies go far beyond classic international trade.

The structure of markets represents the prevalence of economic networks in the coal sector. The global coal market is clearly regulated. The Asian (Pacific) segment, from which Japanese, Korean, Chinese, Indian and Taiwanese corporations receive resources, serve coal suppliers from Australia, Indonesia, Canada, and Rus- 
sia as well as, to a lesser extent, from South Africa. The European (Atlantic) segment involves exporters from South Africa, Colombia, Venezuela, USA, to a lesser extent from Australia. At the same time, the product turnover in the Asian part is twice as high as in Europe, the volume of energy coal is several times higher than the volume of deliveries of coking coal. The largest buyer of coal in the Atlantic market is the Italian ENEL company, and in the Asia-Pacific market - Japanese electric companies. In the coking coal market the largest contracts exist between BHP Billiton and Japanese steel works (Nippon Steel and JFE).

There has been concentration of capital among the exporting companies of coal products for a long time. If in 1998 there were above 16 major players on the arena, only essential part of the whole coal production and trade in these countries proceeded to the Big Four in 5 years, called the united BHP Billiton, Anglo American, Xstrata, and Rio Tinto. However, in 2009 Alpha Natural Resources and Foundation Coal companies completed the merger, having formed the third largest coal mining company in the United States and the Ukrainian Metinvest Company, as a result of the acquisition of United Coal Company, became the sixth largest coking coal mining company in the United States. In early 2012 there was a merger of Glencore with the Swiss mining company Xstrata, so that the company called Glencore Xstrata International became the world's largest exporter of coal for power plants (and a leading manufacturer of copper). After the Big Four, from among the companies of the "second division" one should mention the coal mining companies from Indonesia (Banpu, Adaro, KPC, Arutmin), South Africa (Sasol), Russia (SUEK), Venezuela (Carbozulia) and China (China Coal, Shenhua). The role of the balancing coal market is played by the American Peabody companies and others.

The mode of the turnover of coal is generally established, as a rule, as a result of the achievement of the institutional balance, which means the reluctance of the powerful market players to waste resources on restructuring of agreements.

However, a moment comes when one can not do without it. According to Professor of New York University in Abu Dhabi Georgy Derlugyan it happened under President Clinton (William Jefferson "Bill” Clinton). "The Clinton entourage reproduced the golden autumn of British hegemony in the new historical turn of Belle époque of 1880-1910" [9] and, as a result, failed to cope with China, whose explosive development turned out to be the most unforeseen consequence of globalization policy and gave rise to "bull dynamics", in particular in the coal markets.

Thus, the backwardation of the yearly 2000s associated with the Chinese events caused a sharp increase in the number of short-term contracts and spot transactions. This was especially evident in the Asia-Pacific segment.

Spot-prices or cash-prices determine the immediate delivery and payment of the goods. Spot transactions counts batch, part of batch or butch series. Contracts can be a future price, but with a slight delay. Most often these are transactions between small suppliers or buyers, but they can be in demand among powerful partners connected with long-term relationships - in terms of unstable demand such purchases give these links flexibility, which is extremely important with the addition of suppliers and buyers of coal fuel from the "third world" countries.

Spot contracts in the circle of the coal exporters are bound to two basic prices: FOB Richards Bay (South Africa) that provides the basis of API 4 indices and under FOB terms Newcastle (Australia) for export of the Australian power generating coal.

Among the importers from the Northwest Europe there is a price under CIF ARA (Amsterdam-Rotterdam-Antwerp) terms - API 2 index. Spot prices under CIF terms for Japanese consumers proceed, as a rule, from the statistics of deliveries that have passed through the customs service of the country. Consumers from different regions of the United States are guided by the spot price indices "Central Appalachians", "Northern Appalachians", "Illinois Basin", "Powder river Basin" and "Uinta Basin". The following worldwide known information and analytical companies, same as price agencies, are specialize in information support of spot coal markets: Argus, McCloskey Coal Information Service (MCIS), Platts and South African Coal Report (SACR).

Futures contracts and options are concluded by stock exchanges for the main hubs (Rotterdam, Richard's bay, CSX, Powder River Basin, Central Appalachian, Indo sub-bit, $\mathrm{gC}$ Newcastle). Contracts are formed on the basis of price indices developed by information agencies (Argus, McCloskey, and others, in particular API2, API4, API5 indices and others), trade platforms (Global Coal).

The coal "on papers" is sold much more than physically. In 2012 the volume of financial transactions on power generating coal was 2.2 times higher than the volume of physical supplies (according to Verein der Kohlenimporteure) [4].

ICE (Intercontinental Exchange), NYMEX (New York Mercantile Exchange), EEX (European Energy Exchange) and ASX (Australian Stock Exchange) are specialized on implementation of the financial contracts.

And yet, despite all the stock market innovations, the network capitalism in relations between suppliers and consumers of coal products has not lost its relevance: long-term contracts, practice of bilateral negotiations on the price of the contract. However, the duration of contracts was reduced, as a rule, to 3 years with an annual review of prices.

Any violation of the existing market balance occurs with a change of economic and regulatory regimes (FRR), which serve as a means of meeting the new interests of the parties [9] and is determined by dependence

$$
F R R=\{G ; S ; I ; R ; P\},
$$

where $G$ is the declared set of goals, the achievement of which provides the introduction of this regime; $S$ is the number of entities covered by this regime; $I$ is the num- 
ber of rules, regulations, restrictions, conditions; $R$ is the number of resources available for use during the implementation of this regime; $P$ is the number of policies or strategies aimed at achieving and implementing the declared goals.

The Table shows a hypothetical example of the approach to the selection of the regime to meet the needs for coal resources of the Japanese Metallurgical Corporation.

As an example, let us consider a strategy to strengthen network links through the investment expansion of the Japanese corporations in the development of Bulga Complex production system consisting of a coal quarry and coal mine in the Australian city of Bulga. The dominant owner of a coal company is a Swiss Xstrata Corporation $(68.3 \%)$, the rest of the packages as of 2011 were owned by the Japanese Nippon Oil (13.3\%) and Nippon steel (12.5\%) Corporations, Kawasho Corporation (1.6\%), and Tomen Corporation (4.4\%). By investing in the activities of the Australian coal enterprises, not only do they (investors) contribute to their production development, but also gain control over the activities of coal manufacturers and guarantee the satisfaction of their own needs in such a manner. It is obvious that the regime was necessary for the Japanese metallurgical corporations to achieve a certain balance in the coal markets and without the help of traditional market price mechanisms for balancing supply and demand.

Even in search of fuel to reopen a large coal power plant after the accident at Fukushima Nuclear Power Station, the Japanese power engineers did not come to the market, but began to develop network relationships: they applied to Sakhalin coal miners with a proposal to increase supplies.

Glenn Kellow, President of Peabody Energy, gave his design sample of the market regime set out in statement of bankruptcy. Bankruptcy is also an economic regime. With its help the company intends to reduce the overall level of debt burden and fixed costs, increase operating cash flow, as well as improve its position continuing its activities under the protection of the court.

The post-soviet coal business in Ukraine also started on a network basis but then was transformed into a hierarchical type. Initially, with the tacit connivance of public authorities the informal inter-sectoral cartels were formed subsidized through the mechanisms of state support for mines. Control of business structures over stateowned mines - setting prices for coal products, regulation of sales, supply and investment activities - resulted in the dominance of the cartel institute throughout the second half of the 90s of the last century. And only competition between a formed powerful regional business structures forced them to fall back on the privatization of loss-making at that time associations Pavlohradvuhillia and Krasnodonvuhillia, with significant social and economic obligations. As a result, the majority of domestic coal mining enterprises, regardless of the form of ownership and purpose of products (metallurgical or energy), operate in the mode of centralized planning management. At the same time, even in the best years, the share of coal produced by domestic enterprises operating on a market basis was about $10 \%$ of the national production.

The loss of government control over enterprises producing anthracite in the East of Ukraine caused a fuel crisis in the energy sector of the national scale: half of 14 power plants operate on a low-reactive fuel (anthracite). Replacement of low-reactive fuel with a high-reactive (coals of gas and long-flame grades) fuel from the territory controlled by the government is impossible without serious and expensive reconstruction of power plants. DTEK Company is the main entity of the domestic electric power market operating in the mode of vertically integrated hierarchy like "coal-energy".

Table

An approximate matrix of financial and regulatory regime for coal resources supply to the metallurgical company

\begin{tabular}{|c|c|}
\hline Factor & Description \\
\hline Objective & $G_{1}:$ reliable satisfaction of needs of metallurgical enterprises for coking coal \\
\hline $\begin{array}{l}\text { Entities to which regime } \\
\text { applies }\end{array}$ & $\begin{array}{l}S_{1}-\text { Japanese steel corporation; } \\
S_{2}-\text { coal mining corporations beyond Japan }\end{array}$ \\
\hline $\begin{array}{l}\text { Norms, rules, restrictions, } \\
\text { conditions }\end{array}$ & $\begin{array}{l}I_{1} \text { - inadmissibility of complete purchase of coal mining company abroad and establishment of } \\
\text { branches "from scratch"; } \\
I_{2} \text { - the need to comply with the rules of civilized business (antitrust, anti-corruption; ethical; social); } \\
I_{3} \text { - financial restrictions; } \\
I_{4} \text { - competition between Japanese corporations; } \\
I_{5} \text { - competition from corporations in other countries; } \\
I_{6} \text { - available existing structure of coal markets }\end{array}$ \\
\hline $\begin{array}{l}\text { Resources available for } \\
\text { implementation }\end{array}$ & $\begin{array}{l}R_{1}-\text { economic; } \\
R_{2}-\text { diplomatic (support of the Ministry of Foreign Affairs); } \\
R_{3}-\text { technological (efficient use of resources) }\end{array}$ \\
\hline Policy & $\begin{array}{l}\mathrm{P}_{1}-\text { investment aimed at increasing the production of coal products by foreign manufacturers; } \\
\mathrm{P}_{2}-\text { corporate: establishing the necessary controls over the marketing activities of coal mining } \\
\text { companies; } \\
\mathrm{P}_{3}-\text { modernization of metallurgical production base; } \\
\mathrm{P}_{4}-\text { restructuring of the metallurgical production assets }\end{array}$ \\
\hline
\end{tabular}


In the current conditions of the shortage of coal fuel the Ukrainian electricity market has undergone significant changes: first, the regime of operation of nuclear power was changed to partially compensate for losses of the thermal segment; secondly, an attempt was made to expand imports of anthracites, in particular from the United States and South Africa, for which in March 2016 The National Commission for State Regulation of Energy and Public Utilities (NCSREPU) approved a new methodology for determining wholesale electricity prices. It, in particular, legalized the price of coal for power plants calculated by the formula "the cost of coal in the ports of the Netherlands plus the cost of its delivery to Ukraine and the cost of transshipment in ports" a scheme called Rotterdam+.

On December 28, 2017, NCSREPU issued a resolution on increasing the price of electricity due to an increase in the price of coal and the cost of freight. The forecast wholesale market price for electricity (WMP) according to Rotterdam + method is determined on the basis of the average price in the European market for the last 12 months. For the period from December 2016 till November 2017 the average coal price was $\$ 83.08$ per ton, which is $25.8 \%$ or $\$ 17.04$ higher than the price laid in the WMP for 2017. The average freight rate (the price of coal transportation) from the ports of the Netherlands was $\$ 12.21$ per ton, the average rate of transshipment in the Ukrainian ports $-\$ 7.02$ per ton, which is $24.1 \%$ or $\$ 2.37$ per ton higher than in 2017. According to the forecast of the Ministry of Energy of Ukraine, the volume of coal imports in 2018 for the needs of combined heat and power plants and CHP plants will reach 4.2 million tons or $15.6 \%$ of total consumption.

But as stated in an interview with the Ukrainian newspaper Zerkalo Nedeli dated September 03, 2017 Ambassador Extraordinary and Plenipotentiary of Ukraine to the United States Valerii Chalyi, the supply of American anthracites to Ukraine will be carried out under a direct contract with the Pennsylvania XCoal Company, so that domestic energy has the opportunity to access a reliable and transparent source of resources. The achieved was the result of negotiations in which all leading American companies (Jeddo Coal, Blaschak Coal and Lehigh Anthracite Coal) took part except the above stated, having the opportunity to export anthracites.

In fact this is a natural scheme of network capitalism but not market spot deliveries on which NCSREPU focuses. Moreover, long-term contracts with the prospect of prolongation at least for one year create the preconditions for a significant reduction in the cost of the resource. In other words, there is a substitution of one regime to another in the organization of the power generating coal market in Ukraine.

Conclusions and recommendations for further research. Therefore, as studies have shown, coal markets are in the mode of economic networks (a hybrid form) most of the time and only in cases of significant violations of supply or demand they switch to the market modes of price balancing. At the same time there is a mode activation of balancing the interests of market participants returning the system to functioning in a network mode.

The Ukrainian thermal power engineering functioning mainly as an interindustry hierarchy, on account of losses of the government control over sources of anthracite fuel is to fall back on the establishment of network relations with the suppliers of coal resources, the American companies and the companies from other countries. The system of pricing for coal fuel currently imputed in Ukraine is based on the European market indices, which implies that its Rotterdam+ formula is unsubstantiated and causes negative effects for domestic consumers of electricity.

\section{References.}

1. Babri, S., Jørnsten, K. and Viertel, M., 2017. Application of gravity models with a fixed component in the international trade flows of coal, iron ore and crude oil. Maritime Economics \& Logistics, 19(2), pp. 334-351.

2. He, Y. Y. and Wang, L., 2014. Research on the evolution of the complex network theory based on the international coal trade. Applied Mechanics and Materials. Trans Tech Publications, 672, pp. 2173-2177.

3. Erten, B. and Ocampo, J.A., 2013. Super cycles of commodity prices since the mid-nineteenth century. World Development, 44, pp. 14-30.

4. Zamani, N., 2016. The Relationship between Crude Oil and Coal Markets: A New Approach. International Journal of Energy Economics and Policy, 6(4), pp. 801-805.

5. Wolak, F. A., 2016. Assessing the Impact of the Diffusion of Shale Oil and Gas Technology on the Global Coal Market [pdf]. Stanford University. Available at: <https://ngi.stanford.edu/sites/default/files/16_ Wolak_Stanford.pdf> [Accessed 7 September 2017].

6. Liashenko, V.I., 2012. Financial-regulatory modes of stimulating economic development: introduction to economic regimology [pdf]. Donetsk: NAS of Ukraine, Institute of Industrial Economics. Available at: <http:// www.econindustry.org/SiteDocs/Ljashenko.pdf> [Accessed 24 July 2017].

7. Ménard, C., 2014. The economics of hybrid organizations. Journal of Institutional and Theoretical Economics JITE [pdf], 160(3), pp. 345-376. Available at: <http://brousseau.info/pdf/cours/Menard[2004].pdf> [Accessed 11 May 2017].

8. Christian, D., 2011. Maps of time: An introduction to big history [pdf]. University of California Press. Vol. 2. Available at: <https://cdn.preterhuman.net/texts/history/Christian\%20-\%20Maps\%20of\%20Time\%20-\%20 Introduction \%20to\%20Big\%20History\%20(California,\%202004).pdf> [Accessed 20 December 2017].

9. Derlugian, G., 2013. How the world works. Outline of macrosociological subjects. Moscow: Gaidar Institute Press.

\section{Режимологія вугільних ринків}

\section{О. І. Амоша, Ю. С. Залознова, Д. Ю. Череватський}

Інститут економіки промисловості Національної академії наук України, м. Київ, Україна, e-mail: zaloznova @ nas.gov.ua; cherevatskyi@nas.gov.ua 
Мета. Розгляд теоретичних і практичних аспектів встановлення й зміни режимів функціонування вугільних ринків.

Методика. Основними методами досліджень $€$ наукові абстракції, аналіз і синтез. Виконання роботи передбачає розгляд понять здійснення транзакцій (ринок, ієрархія, гібрид), визначення основних режимів функціонування існуючих ринків вугілля, обгрунтування причин зміни режимів вугільних ринків, використання режимів для досягнення нової ринкової рівноваги, інтерпретація результатів спостережень стосовно українських реалій.

Результати. Ринки вугілля більшу частину часу перебувають у режимі економічних мереж (гібридна форма), і лише у випадках суттєвих порушень попиту або пропозиції переходять на ринкові режими цінового балансування. Одночасно з цим відбувається активізація режимів урівноваження інтересів учасників ринків, що повертають систему до функціонування в мережевому режимі.

Наукова новизна. Доведено, що світові ринки вугілля переважно функціонують у гібридному режимі, а саме, у режимі економічних мереж.

Практична значимість. Українська теплова енергетика, що функціонує переважно в режимі міжгалузевих ієрархій, через втрату урядового контролю над джерелами антрацитового палива, змушена вдатися до встановлення мережевих відносин із постачальниками вугільних ресурсів, тими ж американськими компаніями. Запроваджена на сьогодні в Україні система ціноутворення на вугільне паливо спирається на європейські ринкові індекси, із чого слідує, що властива їй формула „Роттердам + “ безпідставна й призводить до негативних для вітчизняних споживачів електроенергії економічних ефектів.

Ключові слова: вугільна продукція, ринок вугілля, режимологія, режим ринку

\section{Режимология угольных рынков}

\section{А. И. Амоша, Ю. С. Залознова, Д. Ю. Череватский}

Институт экономики промышленности НАН Украины, г. Киев, Украина, e-mail:zaloznova@nas.gov.ua; cherevatskyi@ nas.gov.ua
Цель. Рассмотрение теоретических и практических аспектов установления и смены режимов функционирования угольных рынков.

Методика. Основными методами исследований являются научные абстракции, анализ и синтез. Выполнение работы предусматривает рассмотрение понятий осуществления трансакций (рынок, иерархия, гибрид), определение основных режимов функционирования существующих рынков угля, обоснование причин смены режимов угольных рынков, использование режимов для достижения нового рыночного равновесия, интерпретация результатов наблюдений применительно к украинским реалиям.

Результаты. Рынки угля большую часть времени находятся в режиме экономических сетей (гибридная форма), и только в случаях существенных нарушений спроса или предложения переходят на рыночные режимы ценовой балансировки. Одновременно с этим происходит активизация режимов уравновешивания интересов участников рынков, возвращающих систему к функционированию в сетевом режиме.

Научная новизна. Доказано, что мировые рынки угля преимущественно функционируют в гибридном режиме, точнее, в режиме экономических сетей.

Практическая значимость. Украинская тепловая энергетика, функционирующая преимущественно в режиме межотраслевых иерархий, из-за потери правительственного контроля над источниками антрацитового топлива, вынуждена прибегнуть к установлению сетевых отношений с поставщиками угольных ресурсов, теми же американскими компаниями. Внедрённая в настоящее время в Украине система ценообразования на угольное топливо опирается на европейские рыночные индексы, из чего следует, что свойственная ей формула „Роттердам+“" безосновательна и приводит к негативным для отечественных потребителей электроэнергии экономическим эффектам.

Ключевые слова: угольная продукция, рынок угля, режимология, режим рынка

Рекомендовано до публікації докт. екон. наук О.Ф.Новиковою. Дата надходження рукопису 17.01.17. 